\author{
Alexander V. Silnov \\ https://doi.org/10.26485/AAL/2019/65/7
}

\title{
GREEK CITY: WAR, ART AND 3D-VISUALIZATION
}

\begin{abstract}
The article discusses issues related to the evolution and development of the Greek polis. The types of urban planning and architectural-spatial elements of the ancient city are analyzed. As a graphical application are presented some computer reconstructions performed at the Department of History and Theory of Architecture at St. Petersburg State University of Architecture and Civil Engineering.
\end{abstract}

Keywords: architecture of the ancient world; ancient Greek polis; typology of functional zones and architecturalspatial structures of the Greek city; computer graphics in the work of the architect, three-dimensional visualizations

АБСТРАКТ В статье рассматриваются вопросы, посвященные эволюции развития греческого полиса. Анализируются типы градостроительных и архитектурно-пространственных элементов античного города. В качестве графического приложения представлены компьютерные реконструкции греческих городов, выполненные на кафедре истории и теории архитектуры в Санкт-Петербургском государственном архитектурно-строительном университете.

Ключевые слова: Архитектура античного мира; древнегреческий полис; типология функциональных зон и архитектурно-пространственных структур греческого города, компьютерная графика в работе архитектора, варианты трехмерной визуализации

ABSTRAKT W artykule rozpatrywane są kwestie dotyczące rozwoju greckiej polis. Poddano analizie zasadnicze elementy organizacji przestrzennej miasta, jak i jego architektury. Końcowym elementem rozważań jest propozycja komputerowej rekonstrukcji miast.

Słowa kluczowe: architektura antycznego świata, grecka polis, typologia stref funkcjonalnych i struktur architektonicznych miasta, grafika komputerowa, wizualizacja

The theme of the Greek polis is one of the most important in the science of antiquity; as regards the history of architecture, it can be called the most important. Without knowing the features of this phenomenon, the history of ancient Greek architecture can hardly be fully understood. ${ }^{1}$ As the famous expert on the Ancient World Yuri Andreev has noted: 'among the many questions facing the historians of the ancient world, a special, we can say key - is the question of the polis, its origin, nature and historical role'. ${ }^{2}$ The ancient polis is considered as the basic element of ancient Greek civilization. The many aspects of it - socio-political, economic, artistic and many others have been subjected to study by various areas of modern science of antiquity. However, we believe that the circumstances and causes of this phenomenon are incomplete without its study from the point of view of the history of architecture, urban planning and so-called 'military architecture' - the history of the art of fortification. ${ }^{3}$ There is a concept of a citystate, known to us from the works of ancient Greek authors - poets, historians and philosophers. The image of free citizens living in an independent city that has become an entire state is reflected in the work of the poet Alcaeus from the Mytilene, who informed his listeners that the main thing in the city is its citizens:

\footnotetext{
Суриков 2010: 8.

2 Андреев 2003: 25.
}

3 Сильнов 2015: 47-54. 
Do not defend yourself with

a threatening acropolis,

Not a solid stone wall,

The towers, the and the walls of

the city are its brave citizens! ${ }^{4}$

In the classical era, this idea sounded even more clearly:

If you continue to want to rule the land, It's better for men not to desert their post. After all, the fortress, tower or shipAmounts to nothing when the defenders have fled ${ }^{5}$

So, already by the 7 th century $\mathrm{BC}$ the polis becomes not only a city-state, but also a civil society. Moreover, the Greeks very early became aware of this situation, regardless of whether the territory of this formation was at their disposal or not. In the famous passage of Thucydides dating back to 413 BC, the Athenian commander Nikias addresses to his soldiers during an forced retreat from Syracuse 'After all, the city is people, not walls and not ships without people'. ${ }^{6}$ It can be argued that by the VI century BC. there was an understanding of the state as a civil society. To the 4th century BC this thesis was reflected in theoretical works primarily in the works of Aristotle. In his 'Politics' the results of almost two hundred years of development of the historical and social nature of the policy are formulated. ${ }^{7}$ Its provisions in relation to the evolution of the concept of a polis are reduced to the following: the natural combination of a man and a woman leads to the creation of a family; no less natural combination of master and slave leads to the creation of a household - the so-called oikia. Further evolution brings together several families in koma a village; and the union of several villages allowed the concept of polis to appear. The meaning of the existence of a polis is to provide its population with the necessary territory and prosperity, which is the highest and most perfect form of life in human society. The ancient polis, which expanded along with Alexander the Great and his followers, inherited the main characteristics of the classical city-state, and inevitably evolved further - in accordance with new circumstances. The Hellenic - or Hellenized city - in the era of the Diadochoi becomes the main element of the new world, which expanded to vast

\footnotetext{
4 Alcaeus 1971: fr. 426.

5 Софокл, Царь Эдип. 1988: 32.

Thuc., VII, 77, 7. 1993.

Arist., Pol., 1983: 38-52.
}

territories from the coast of Asia Minor to the borders of modern Afghanistan and India.

Greek cities were built on territories with the most diverse climatic conditions. Even in mainland Greece, they were significantly different from each other. For example, in northern Greece - in Epirus and Thessaly with a harsh climate due to the Pindus mountain range, livestock farming was widespread. On its other side - in Thessaly, agriculture developed. In Central Greece - Phocis was unsuitable for agriculture; while Boeotia was famous for its wheat and fat herds of cattle. Central Greece - primarily Attica, was famous for olive trees, viticulture and silver mines. In the Peloponnese, where the main competitors of Athens, Sparta, were located, wheat was grown (in Elis and Argolis); while the 'happy' (as defined by poets) Arcadia was famous for its pastures for cattle breeding. In the south of the Peloponnese - Messenia and Laconia, with their humid climate, there was a convenient place for the cultivation of fruit trees (olive) and wheat. All these areas were separated from each other by mountain ranges and, as writes Tatiana Savarensky, 'the main geographical factor that contributed to the development of individual Greek regions and their entry into trade relations with the outside world was the Mediterranean Sea' ${ }^{8}$ The Greeks, choosing a place for new cities, were guided by considerations of strategy and defense - the unity of these principles can be traced in all cities of the Mediterranean and Black Sea regions. As a rule, new colonies were built on hilltops with outcrops of cliffs, protruding into rocky capes (Panticapeaum, Pergamum, Priene); protruding into the sea, either on plateaus near the coast, protected by ravines and slopes (Olbia); or on a peninsula with convenient harbors on its sides (Miletus, Piraeus, Selinus). In the choice of a place for a future city, along with the military aspects and the convenience of communications, the problem of water supply was of great importance (just recall the legend told by Vitruvius about the architect Dinocrates, who was going to build a city on Mount Athos in the form of a giant statue of Alexander). ${ }^{9}$

Thus, the fathers of Greek colonization, which achieved such brilliant results already by the VI century BC, always followed the basic principles of ancient urban planning and fortification, formulated by this time in the writings of architects, historians and philosophers. According to Moscow archaeologist Tolstikov, these principles include: safety and profitability of a strategic location;

\footnotetext{
8 Саваренская Т.Ф. 1984: 60.

9 Vitruvius, De archit., II, 1-44: 1936.
} 
availability of sources of drinking water and favorable for healthy climatic conditions; proximity to the sea or navigable river; the presence of a secure harbor protected from the winds. ${ }^{10}$ In connection with these rules, researchers, as a rule, associate the methods of regular planning that arose, apparently, in the process of Greek colonization in the 7th-6th centuries BC. As notes Tatiana Savarenskaya, 'the emergence of a regular layout of Greek cities is usually associated with the name of a native of Miletus an architect and mathematician Hippodamus, who lived and worked in the 5th century. BC. However, the data of modern archeology convinces us that many cities built at the end of the VI century BC, already had regular plans'. ${ }^{11}$

Functional zones of Greek cities were formed on the basis of the general urban planning situation that arose in each particular case. With all the variety of geographical, climatic and fortification features of each city, it is possible to identify general compositional patterns. Researchers note that the presence of two functional zones - the city center (polis ) and its rural territory (chora) - should be considered as a fundamental feature of the Greek city. ${ }^{12}$ The borders of the chora could coincide with the borders of the state (Athens, Sparta, Miletus); but they could also be located in a zone that did not directly touch its borders (Tauric Chersonesos). Thus, a functional unity of the polis and chora was created as an independent urban development unit consisting of a city and a community.

We determine the presence of three primary functional areas of the Greek city:

1. The polis is the highest level of urban settlement, performing the functions of the main administrative, political and religious center. This center was the center of the civil community, both with full citizens and those who were deprived of these rights (women, metics, slaves). According to our sources - first of all, Strabo and Pausanias - the following types of urban buildings can be distinguished as part of the policy: administrative buildings; agora; theaters gymnasium; main shrines (temples).

2. Polisma (quasi-urban center) - is an intermediate urban formation between the polis and the chora. Polisma performed in the chora certain functions of the central urban settlement, but never possessed all of their fullness. Our sources indicate that the population of such polismas did not form

\footnotetext{
10 Толстиков В.П. 1981: 26.

11 Саваренская Т.Ф. 1984: 60.

12 Хапаева Д.Р. 1988.
}

a separate community, but was part of the polis as phratries or separate demos, which is also confirmed by epigraphic data. So, according to Strabo, the polisma Fisk formed 'the deme Fisk' in the polis of Lindos, ${ }^{13}$ for which he uses the term polichnion. This specific form of settlement could have all the main functions of the city (harbor, fortifications); but they lacked administrative buildings - a theater, gymnasiums, etc.

Thus, the difference between polis and polisma was that despite the presence of such city-forming elements as a harbor, a system of defensive fortifications or a sacred site with a temple the residents of the polisma did not have their own chora - a land plot. Thus, the primary functional area of the polisma played the role of an appendage to the main urban entity - the polis. This interesting urban formation was widespread in the states of central Greece and Asia Minor; but starting from the 4th century BC, in an era of dramatic changes in the political and socio-economic situation, polismas and small nations begin to be absorbed by larger ones.

3. Kome (village) - the third type of the primary functional zone of the Greek city. The kome produced agricultural products and was a compact land allotment - kleros (land), which was owned by free citizens of the polis.

A typical example of such kleroi is Tauric Chersonesos, a Milesian colony formed in the 7th century BC with a polis on Cape Chersonesus and with chora on the Tarhankut Peninsula. The construction of such settlements was deprived of public facilities, and consisted of separate land plots and small estates with a well-defined defensive function - protective walls and towers. For Tauric Chersonesos such precautions were quite understandable in connection with the constant threats of Scythian raids. The examples we know from the works of Strabo and Pausanias testify that the decline in production in the chora inevitably led to the decline of the polis itself (this is testified to by the fate of cities such as Tanagra, Megara, Sicyon, etc.). Researchers note that the inextricable unity of the main functional areas of Greek cities is an essential feature of Greek urbanization; that a fullfledged idea of the life of the ancient city can be obtained only by taking into account the interconnections of all changes in functional zones. Greek polis born as a result of complex colonization processes of the 8th-6th centuries BC, reached its peak by the $\mathrm{V}$ century $\mathrm{BC}$; and generally had similar 
stages of development associated with the presence of the main functional zones that determined the socio-economic and urban development aspects.

The study of the types of planning structures of the Greek city is naturally associated with such disciplines as the history of urban planning and landscape design. Numerous studies on this topic, as a rule, were carried out in the context of general courses on the history of urban planning art and landscape planning and, therefore, for our topic only the preliminary materials. In the work of A. Marquand their expressive characteristic is given: 'analyzing the various types of Greek architectural monuments, we must show the techniques that the Greeks used to design their cities; ways to protect them using walls and towers; the construction of temples for prayers to immortal gods; construction of public buildings for city management; market areas for trade; gymnasiums, stadiums, baths and other facilities for physical development; libraries, museums and theaters for the intellectual development of people; palaces and houses for living in the city; ships for traveling by sea; and, finally, memorial and burial structures for the dead'. ${ }^{14}$ Russian researcher Andrei Bunin, giving a general description of the development of Greek urban development, notes that in most cases, the city-cities had small sizes and a small population..$^{15}$ A medium-sized city did not exceed the size of 50-60 hectares, where 5-7 thousand inhabitants lived. Only in the classical era and, later, in the Hellenistic, do cities with a population of up to 100 thousand inhabitants appear, which are the so-called metropolises - centers of Greek colonization. To its heyday in the V century BC Athens occupied an area of 220 hectares and had about 100 thousand inhabitants. Moreover, the sea harbor of the city - Piraeus was not inferior in area to Athens, and could be considered an independent urban construction unit. The capital of Hellenistic Egypt Alexandria to the 1st century BC totalled up to 300 thousand inhabitants; and in the Roman era reached about a million people.

In general, we can conclude that already in the era of the VII century BC the main types of primary functional zones and planning structures of the Greek city were formed. In the future, with the development of theoretical knowledge, the appearance of the first treatises on various branches of knowledge with sections related to architecture and military affairs, there is a qualitative growth

14 Marquand A., 1909: 286.

15 Бунин А.В., Ильин Л.А., Поляков Н.Х., Шквариков В.А. 1945: 35. and the emergence of various forms of urban structures. The development of military aspects in the history of the polis development during all periods of its life had a priority.

The Department of History and Theory of Architecture at St. Petersburg State University of Architecture and Civil Engineering conducts research into the scientific reconstruction of visual images of the ancient city. So, the author of this article, together with students of the faculty of architecture, performed a series of computer reconstructions of the ancient cities of the Hellenistic era (see illustrations 1-3). Three-dimensional models of antique polis, created taking into account modern historical and archaeological data, allow you to see the 'living' images of a bygone era, touch beautiful examples of ancient architecture and the art of urban planning.

\section{Literature}

Суриков И.Е., 2010. Греческий полис архаической и классической эпохи / Античный полис. Курс лекиий. Университет Дмитрия Пожарского. Москва.

Андреев Ю.В., 2003. Раннегреческий полис (гомеровский период). Избранные статьи. Издательский Центр «Гуманитарная академия», Санкт-Петербург.

Сильнов А.В., 2015. Эллинистический город: Градостроительство, фортификаиия, полиоркетика / Современные проблемы истории и теории архитектуры/ Доклады научно-практической конференции СПбГАСУ. Санкт-Петербург.

Sappho et Alcaeus. 1971. Fragmenta. Eva-Maria Voigt (ed.). Polak and van Gennep, Amsterdam.

Софокл. 1988. Трагедии. Пер. С.В. Шервинского, Царь Эдип. Москва.

Thuc., VII, 77, 7. 1993. Фукидид, История. Москва.

Arist., Pol. 1983. Аристотель. Сочинения, m. 4 / Общ. Ред. А.И. Доватура, Москва.

Саваренская Т.Ф. 1984. История градостроительного искусства. Т. І. Москва.

Vitruvius, De archit., II, 1-4. 1936. Витрувий. Десять книг об архитектуре. Пер. Ф.А. Петровского. Москва.

Толстиков В.П. 1981. Фортификаиия античного Боспора. T.2. Приложение I, Москва.

Саваренская Т.Ф. 1984. История градостроительного искусства. Т. І. Москва.

Хапаева Д.Р. 1988. Урбанистические прочессы в античной Гречии (в основном по данным 
Страбона и Павсания). Автореферат на соиск. уч. ст. к.и.н., Ленинград.

Marquand A., 1909. Greek Architecture. Handbook of Archaeology and Antiquities. Macmillan Company. New-York.

Бунин А.В., Ильин Л.А., Поляков Н.Х., Шквариков В.А. 1945. Градостроительство. Издательство Академии Архитектуры СССР. Москва.

Silnov Alexander

ORCID 0000-0002-5039-9561 Saint Petersburg State University of Architecture and Civil Engineering alexsilnovarchitect@yahoo.com

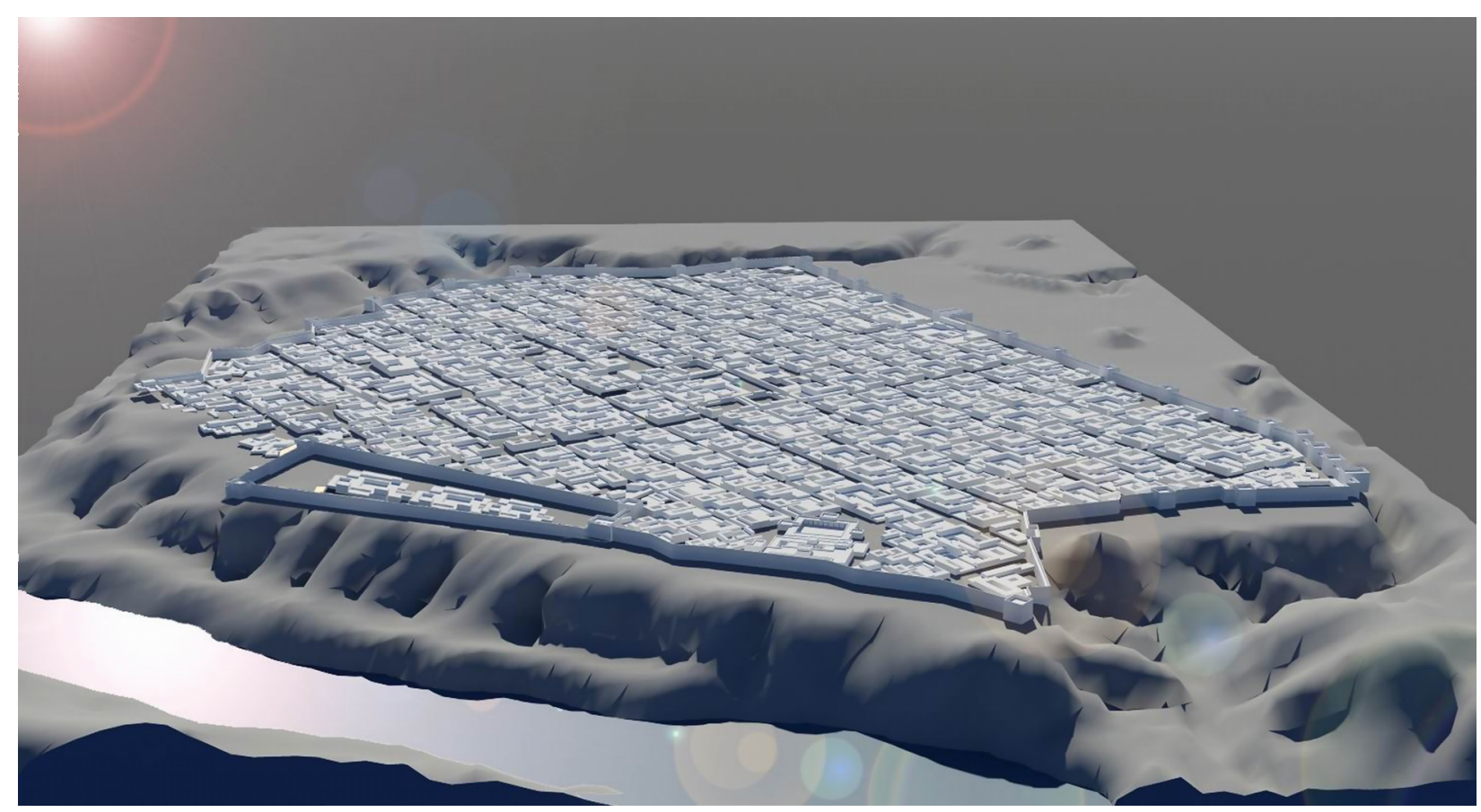

Drawing 1. Computer reconstruction of the Greek city of Dura Europos in Syria in the 1 st century BC. Research project and visualization by A. Silnov

Photo from archive of Department of History and Theory of architecture. 2016 C

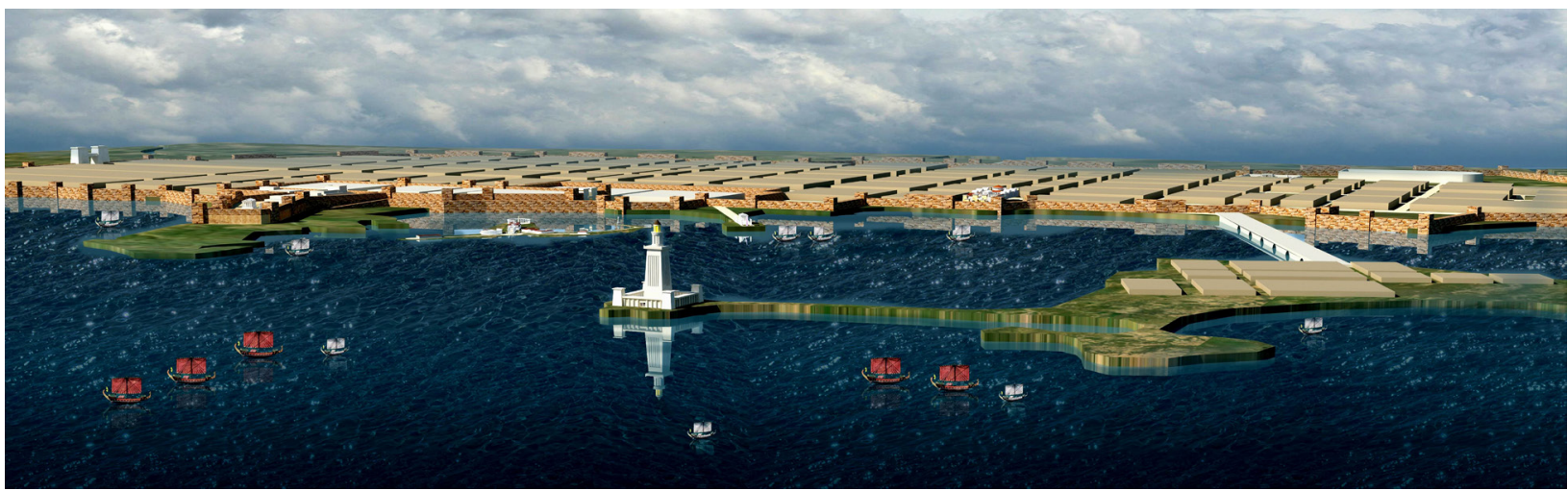

Drawing 2. Computer reconstruction of Alexandria in Egypt.

Research project and visualization by A. Silnov and E. Makarova Photo from archive of Department of History and Theory of architecture. 2015 (C) 


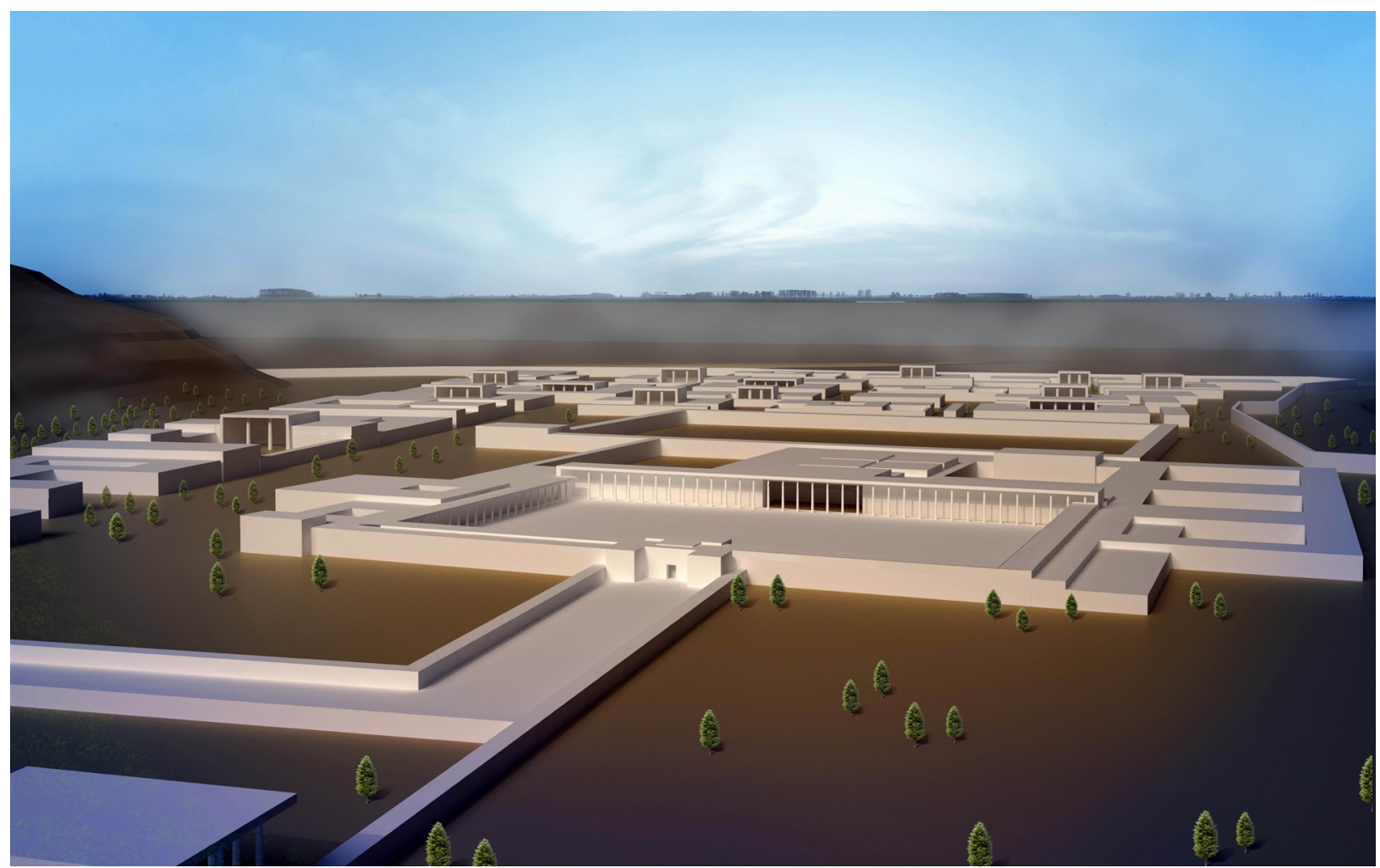

Drawing 3. Computer reconstruction of the Alexandria-on-Oxus in Baktria. Research project and visualization by A. Silnov and O. Romanova

Photo from archive of Department of History and Theory of architecture. 2016 C) 